\title{
How Can We Account for Persisting Educational Inequalities in Rural China
}

\author{
Jason Hung $^{1}$ \\ ${ }^{1}$ Institute of Education, University College London, London, the United Kingdom \\ Correspondence: Jason Hung. E-mail: sociowriting@jasehung.com
}

Received: May 17, 2020

doi:10.5539/ass.v16n7p46
Accepted: June 1, $2020 \quad$ Online Published: June 17, 2020

URL: https://doi.org/10.5539/ass.v16n7p46

\begin{abstract}
The ultimate purpose of the development of this essay is to inform Chinese policymakers on how they can better implement education-related policies to minimise spatial and gender disparities in, and multi-faceted barriers to, educational opportunities. This essay, firstly, highlights policies that address spatial and gender disparities in education and structural barriers to girls' education with the support of the frameworks of Women in Development (WID) and Gender and Development (GAD) in rural Chinese contexts. Secondly, this essay outlines the problems of rural female underdevelopment in least educationally and financially developed Chinese regions based on critical analyses on relevant statistics and studies. Thirdly, in spite of the Central Government's and non-governmental organisations' (NGOs) endeavours to facilitating education development, this essay investigates and analyses how gender inequalities in education persist due to the unaddressed multi-faceted barriers to girls' education. These multi-faceted barriers include social, cultural, economic and otherwise educational impediments faced by rural poor Chinese girls. Lastly, this essay suggests state and NGOs' policy and intervention to address such structural barriers to education and enhance rural girls' decision-making powers and educational opportunities in the long-term.
\end{abstract}

Keywords: education development, gender development, decision-making, Confucianism, educational policies

\section{Introduction}

In 2018, out of 1.4 billion Chinese population, 41\% lived in rural China (The World Bank, 2020a, 2020b). Rural children are either living with both of their parents, left behind by or migrating to cities along with parent(s). Left-behind children are defined as rural individuals under the age of 18 whose parent(s) migrate(s) to a different location for work for more than 6 months (Lu, Lin, Vikse, \& Huang, 2016, p. 59). Migrant parents usually leave girls behind in rural areas but take boys to cities (Zhao \& Yu, 2016, p. 3469).

By the end of 2016, rural poverty rates nationwide had reached $4.5 \%$, with 43 million impoverished individuals living in the countryside (Xue \& Zhou, 2018; Hannum, Park, Brauw, \& Rozelle, 2012). In order to alleviate poverty, the Central Government of China aims at promoting the Education for All (EfA) campaign (Kipnis, 2011, p. 5; Liu, 2008). The 1995 Education Law states, "Educated population shall enjoy equal rights under the law such matters as school entry, grade promotion and employment... (Su, 2011, p. 19)" Alongside poverty alleviation, championing the EfA campaign is conducive to the development of better health and wellbeing towards rural populations. For example, JieZhang, Shuiyuan Xiao, and Liang Zhou (2010, p. 773) examined the suffering of mental disorders, including mood disorders, schizophrenia and anxiety disorders, among rural Chinese cohorts aged between 15 and 34. Face-to-face interviews were conducted with 392 non-fatal suicide victims and 416 individuals from the control group. Findings revealed that lower education level was related to higher degree of mental illnesses and suicidal acts. Here 16 rural counties and interviewees were randomly selected from three provinces, namely Liaoning, Hunan and Shandong, based on the 2005 census database (ibid: p. 774). These provinces are among the most financially and educationally underdeveloped Chinese regions, so findings are indicative of the sufferings encountered by most vulnerable rural cohorts. However, surveying in only 16 counties within three provinces might limit the representativeness of the findings. Further studies should be carried out in order to understand the nuanced relationships between mental health, suicidal acts and education level in wider rural contexts. Beyond the health perspective, education has a range of instrumental personal economic roles, such as facilitating job hunt, ensuring better working conditions, enjoying better consumers' information, and so forth (Robeyn, 2006, p. 71). For girls, especially, education is a tool for 
empowerment where girls with better education level have more positive feelings about their self-worth as female. These better-educated girls are more capable of avoiding domestic and sexual violence, and are more likely to access to a variety of material (such as lands and properties) and basic (such as food and water) resources (Stromquist, 2015, p. 64). Other benefits of education include helping prepare children for parenthood and political participation, in addition to learning the right to have rights and enhancing social cohesion (Robeyn, 2006, p. 75).

The ultimate purpose of the development of this essay is to inform Chinese policymakers on how they can better implement education-related policies to minimise spatial and gender disparities in, and multi-faceted barriers to, educational opportunities. This essay, firstly, highlights policies that address spatial and gender disparities in education and structural barriers to girls' education with the support of the frameworks of Women in Development (WID) and Gender and Development (GAD) in rural Chinese contexts. Secondly, in spite of the Central Government's and non-governmental organisations' (NGOs) endeavours to facilitating education development, this essay investigates and analyses how gender inequalities in education persist due to the unaddressed multi-faceted barriers to girls' education.

\section{Women in Development (WID)}

The WID Office in the United States Agency for International Development (USAID) was set up in 1973 by the Percy Amendment. Broadly speaking, in response to female marginalisation from the engagement in skilled labouring jobs, the office believes that women should be included in developmental assistance schemes in order to raise the efficiency of the process of development (Jaquette, 2017, p. 244; Calkin, 2015, p. 297). Here the WID approach emphasises on the importance of including women in development planning, while not necessarily challenging the multiple sources of women's subordination (Aikman \& Unterhalter, 2005, p. 17). WID theorists are concerned with male biases on women (Koczberski, 1998, p. 398). They aim at delivering more economic independence to women and leveraging to challenge patriarchal norms in household settings (Jaquette, 2017, p. 244).

In this approach, education is interpreted by schooling and development is referred to the economic growth, social cohesion and sometimes improved governance (Aikman \& Unterhalter, 2005, p. 18). The approach challenges gender gaps in education by fostering more girls to attend school. In specific, the framework aims at minimising the gaps by equalising the amount of resources distributed to boys and girls.

This approach, to little extent, values the gendered processes of learning, working conditions and expectations on female teachers, and the gendered interpretation of the images children see in textbooks (ibid). The approach also fails to concern with what and how girls learn at school (ibid: p. 20).

\section{Gender and Development (GAD)}

Since WID projects had a limited focus on the improvement of access to resources for individual women, the GAD approach, emerged in the late 1980s, has addressed its shortcomings and emphasised on the significance of gendered power structures of inequality (Jaquette, 2017, p. 247). GAD theorists oppose the WID framework by arguing that the sole practice of female inclusion cannot ameliorate gender equality in education. Instead, these theorists claim that gender inequality can only be effectively addressed by taking political actions to alter gendered structures of power (Aikman \& Unterhalter, 2005, p. 21). These actions include challenging gender discrimination in the legal system, sexual violence in household settings, the lack of political representation and discrimination at work. Under the GAD framework, structural barriers to gender equality can expectedly be eradicated by removing unfair laws and labour market practices against women, challenges against women's decision making and inequitable processes in respect of the distribution of time, money and educational resources by gender (ibid: p. 23).

GAD calls for gender mainstreaming and gender budgeting. Gender mainstreaming aims at legitimising gender equality as a core value that is reflected in development choices and institutional practices for societies, and facilitates female presence as decision makers (ibid: p. 25).Under such a scheme, GAD theorists stress on participatory development which recognises the diversity of women's experiences and enables individuals' definition of their strategic gender needs for themselves (Jaquette, 2017, p. 247). The GAD approach was criticised that it is overly women-focused and the exclusion of male from participating in relevant projects and programmes fails to foster gender equality as: the dichotomous categorisation and stereotypes that men and women are oppressors and victims respectively cannot be challenged; hostility between men and women may potentially increase; and any success in women-only projects is constrained since men play a dominant role in gender relations (Wanner \& Wadham, 2015, p. 17). To achieve gender mainstreaming, the United Nations Commission for the Advancement of Women (UNCAW) urges men to be involved in developing structural 
changes within the major economic, social, cultural and political institutions which uphold male powers and maintain women's disempowerment (ibid: p. 23). Alternatively, gender budgeting concentrates on identifying the gendered expenditure of a departmental budget and inputting resources on elements that can yield benefits to women (Aikman \& Unterhalter, 2005, p. 26).

\section{Status Quo - Enrolment and Dropout Rates}

In impoverished rural Chinese areas, children and youths encounter substantial difficulties in accessing educational opportunities, especially in non-compulsory education (Epstein, 2017 [1991], p. xiii). In 1992, for example, a cohort of 156,981 children entered primary schools in rural China. In 2004, only $8.2 \%$ of these rural students completed secondary education, while the secondary education completion rate for their corresponding cohort in urban China was $61 \%$. Among those $8.2 \%$ rural Chinese students, only $76 \%$ (i.e. 9,783 out of 156,891 students) sat for the College Entrance Examination (CEE), as a prerequisite to compete for university places (Yang, 2010, p. 195). The study indicated dropout rates were significantly higher in rural China. However, this longitudinal study failed to disclose the retention rates which a loss of participants with certain socio-demographical or socio-economic characteristics might lead to biases in findings. According to a policy brief published by Rural Education Action Program (REAP) at Stanford University, by the late 2000s, while over $90 \%$ of rural students attended junior secondary school, less than $30 \%$ enrolled into senior secondary school and only $1.3 \%$ entered universities (Golley \& Kong, 2013,p. 16). The low enrolment rates for senior secondary and tertiary education were primarily due to the unaffordability of rural households and the prerequisite to pass a standardised examination in order to enrol (REAP, 2007, p. 2). In addition, based on findings of eight recent studies carried out between 2011 and 2015, the cumulative average dropout rates across junior secondary schools ranged between 17.6 percent and 31 percent, which were between six and 12 times higher than the official $2.6 \%$ dropout rate published by the Central Government (Shi, Zhang, Ma, Yi, Liu, Johnson, Chu, Loyalka, \& Rozelle, 2015, p. 1052). In those eight studies, surveys were carried out in relatively impoverished rural areas. However, the official statistics were developed based on overall census data, which means data collected in relatively rich rural regions were taken into account. Such a data collection gap might help explain why official statistics displayed a by far lower premature dropout rate.

Aggregating data from 27 surveys carried out in rural areas of ten Chinese provinces from 2009 to 2013, where random sampling was applied, Chengchao Zhou, Sean Sylvia, Linxiu Zhang, Renfu Luo, Hongmei Yi, Chengfang Liu, Yaojiang Shi, PrashantLoyalka, James Chu, Alexis Medina and Scott Rozelle (2015, pp. 1966-7) found that both left-behind children and children living with both parents had 19\% dropout rates from junior secondary school. These surveys were predominantly conducted in relatively poor rural areas in China. However, researchers failed to identify the exact causes of the premature dropouts. Using individual-level data from the 2006 China Health and Nutrition Survey (CHNS) where random cluster sampling was applied to select rural respondents from nine Chinese provinces, Ming-Hsuan Lee studied 913 rural children and youths aged between six and 18. These provinces include those most impoverished regions, including Hunan, Jiangsu and Shandong. Findings revealed that left-behind rural children were $37 \%$ less likely to enrol into school than rural children as a whole (Lu et al., 2016, p. 59). For the group aged between 15 and 18, left-behind rural children were $85 \%$ less likely to attend school, relative to all rural children (Lee, 2011, p. 173). However, it was statistically insignificant to claim that rural boys and girls displayed different school enrolment rates. It is noteworthy that Lee's study did not examine any school enrolment gaps between left-behind rural boys and girls, but rural boys and girls as a whole.

\section{State Policies to Address EfA}

Since the launch of Chinese economic reforms in 1978, the open and reform policy under the leadership of the former Chinese President Deng Xiaoping identified education massification as a pathway for advancing science and technology, and therefore, economic reconstruction (Deng \& Kim, 2004, p. 144). In the 1980s and 1990s, the Central Government of China still spent relatively insignificant amount of financial resources on rural education development. This was because rural education produced relatively lower private and social rates of returns. In those two decades, the average returns from education in developing countries were over ten percent, whereas those from rural China were below five percent (Brauw \& Rozelle, 2007, p. 58). A rise in governmental investment in education could stimulate agricultural production and establish employment opportunities in the non-agricultural sector (Fan, Zhang, \& Zhang, 2004, p. 396). John Knight, Li Shi and Deng Quheng (2010, pp. 8-9) echo that education raises the opportunities for individuals to escape from farms and engage in non-farm activities. The delivery of better-quality education, additionally, improves longer-term labour productivity.

To address the profound issue of under education faced by rural and female populations, the Central Government 
began the Free Compulsory Education Reform (FCER) to reduce educational fees for rural students and promote compulsory education in villages from mid-1980s (Tang, Zhao, \& Zhao 2020, p. 602). The aforementioned compulsory education law purportedly aimed at prioritising educational equality nationwide (OECD, 2016, p. 28). Even each school-aged child or adolescent who is among the lowest socioeconomic status (SES) is expected to finish mandatory education (Yue, et al., 2017, p. 97). However, such a state policy alone could hardly attain educational equality as ample avoidable or remediable barriers to education in cultural, social, economic and demographic contexts, which are discussed below, particularly faced by disadvantaged populations, could not be fully addressed. Instead, the policy raised spatial and gender parity in education where unprivileged populations were given schooling opportunities but to a level less than their more advantaged counterparts. Here improving spatial and gender parity are predicators of progress towards realising EfA goals (Seeberg, Ross, Liu, \& Tan, 2007, p. 112). Such a reform addressing parity in education, yet, does not engage with more challenging notions of educational equality (Aikman \& Rao, 2012, pp. 213-214). Neither does it facilitate discussions on how unprivileged cohorts, such as poor rural girls, could be empowered and transformed (Unterhalter and North, 2010, p. 399). Increasing poor rural girls' opportunities to schooling could, to some extent, achieve WID goals by narrowing the gender gaps in school enrolment rates. However, such a state policy fails to fully ensure, for example, that equal numbers of male and female teachers are employed, and equal numbers of male and female images are appeared in teaching materials (Aikman \& Unterhalter, 2005, p. 19). Therefore, the policy does not completely fulfil the objectives of the WID framework.

To further facilitate the access to compulsory education for disadvantaged school-aged children and adolescents, the Central Government announced the "Two Exemptions, One Subsidy" (TEOS) policy in 2001. The policy states that local governments in nationally designated poor counties would exempt the textbook and school fees from school-aged children, alongside giving subsidies to them for accommodation in boarding schools (Knight et al., 2013, p. 153; Wang, 2018, p. 168). Despite the implementation of the such a policy, there was then no guarantee, particularly in impoverished areas, that all students could finish nine years of compulsory education (Brauw \& Rozelle, 2007, p. 62). This was because while the exemption of textbooks fees targeting poor children was fully financed by the Central Government, the subsidies for living and other education-related expenses were financed by local governments (Shi, 2016, p. 1793). Impoverished local governments were financially less capable to support their villagers for schooling, leading to the circumstance of children's premature dropout and the failure of realising universal compulsory education in least developed Chinese regions. Poor local governments' financial constraints have exacerbated since 1994 where China has been practicing a decentralised fiscal system and has been increasingly relying on local governments to fund education (Dollar, 2007, p. 1). Local governments located in most underdeveloped areas often lack the financial capacity to provide state-subsidised compulsory schooling, particularly post-primary schooling, to their villagers (Lee, Yu, Huang, \& Law, 2016, p. 3; Liu, 2004, pp. 6, 12; Hannum, 2005, p. 278; Rong \& Shi, 2001, p. 108). The TEOS policy satisfied with the WID framework by exempting or subsidising marginalised rural children the relatively direct costs on school access. However, those relatively less direct costs, such as digging latrines and providing food and clean water, were overlooked (Aikman \& Unterhalter, 2005, p. 19). The lack of financial capacity among poor local governments could not be ameliorated unless the decentralisation system and its implications of significant financial inequalities by regions could be challenged institutionally and politically by, for example, raising Central Governments' financial responsibilities on the distribution of educational resources (ibid: p. 21).

As a status quo, without adequate local governments' financial support, households in many poor rural areas are unable or unwilling to pay the required, unsubsidised education fees for their children, especially daughters (Park, 2007 , p. 56). However, this essay primarily focuses on discussing relevant state policies on rural education development, where education-related support delivered by alternative bodies, such as NGOs and friends, are addressed to a lesser extent and overlooked respectively.

In 2006, only children from dozens of counties, largely located in rural West of China with economic underdevelopment and unfavourable natural conditions, were denied the entitlement to nine-year compulsory education (Wang, 2010, p. 3).Therefore, the promotion of universal compulsory education from late $20^{\text {th }}$ century through 2006 had been rather successful. From 2006 onwards, the TEOS policy was integrated into the New Mechanism for Assured Funding for Rural Compulsory Education (NMAFRCE) programme. The integrated programme strengthened the state subsidies for rural compulsory education by, for example, inputting more financial resources into the maintenance and reconstruction of rural secondary and primary school establishments, and facilitating the issuance of salaries to rural secondary and primary school teachers. By October 2006, the Central Government had collected RMB 13.3 billion (US\$ 1.88 billion) in reform funds (Ding, 2008, p. 30). While the integrated programme raised the coverage of both direct and indirect costs to school 
access, relevant studies (e.g. Fu \& Liu, 2006; Zhou, 2006; Zhang \& Hou, 2006; Meng, 2007; Ding, 2008) carried out in most impoverished rural areas in mid-late 2000s showed that the amount of subsidies given to students were "hand-to-mouth finances" and could only waive their miscellaneous, textbooks but not otherwise education-related fees. Especially for poor rural children who would like to enter un- or under-subsidised post-compulsory education, the integrated programme, with an increasing yet limited coverage of the public funds, failed to support their education fully. This might explain why rural school-aged cohorts aged 15 or above, and especially those aged 18 or above, were more likely to drop out from school. As a result, raising state subsidies for rural education development might not necessarily lead to satisfactory outcomes. The Central Government should consider collaborating with external bodies to fund poor rural children to attend school. For example, the Central Government only allows Rotary International, a renown international charity, to organise and run community outreach programmes in Hong Kong, Macau, Guangdong and Inner Mongolia, but not in the rest of China. The Central Government should further open up the country to community development by enabling more external NGOs to deliver education-related services in rural China, especially in regions which are most educationally deprived.

\section{The Importance of, and Barriers to, Girls' Education}

In 1990s, two-thirds of illiterates nationwide were women. In response, in 1996, the Ministry of Education proposed a 10-item integrated intervention to enhance the provision of education opportunities for school-aged girls (Seeberg et al., 2007, p. 117). According to Save the Children's State of Mothers annual report published in 2005, "Educating girls today will create lasting change for the next generation. When mothers do well, so do their children" (ibid: p. 115). Increasing the years, and improving the quality, of female education can limit population growth, raise public health and enhance the availability of human resources. Beyond the explanations of the WID approach, such a claim highlighted in the report demonstrated that raising the quality rather than just the quantity of female schooling is also beneficial to rural development (Aikman \& Unterhalter, 2005, p. 20). Existing literature supports that the quality of education girls receive is linked to whether girls encounter gender inequalities after they finish schooling (Aikman \& Unterhalter, 2005, p. 20; Aikman \& Rao, 2012, p. 214). Monazza Asiam and Geeta Kingdom (2012, p. 211) further argue that the quality of education is a strong indicator of gender equality in the labour market. In China, the quality of education in state schools is below par than that in private schools. Yet, rural girls are disproportionately unlikely to attend private schools since educational expenditures are spent on rural boys more than on their female counterparts (Brown \& Zong, 2017, p. 100). Therefore, even when the Central Government has improved gender parity in education, the lower quality of education received by rural girls might still foster gender inequalities in the labour market in the long-term.

Further to the claim made in the report, relevant survey findings unveiled that girls' enrolment has a stronger positive effect on the enhancement of household financial performance than boys' enrolment. Controlling household income level and other relevant variables, household assets, based on net worth and liquid assets, are positively related to girls' years of schooling but unrelated to that of boys (Deng, Huang, Jin, \& Sherraden, 2014, pp. 191-192). However, the authors kept maternal variables (namely mother's marital status, employment status, education) but not paternal variables constant, therefore paternal factors might intervene the survey findings, leading to some extent of biases and limiting the validity of the results.

Official statistics showed that the total primary school enrolment rate of girls raised from $96.31 \%$ in 1995 to $98.93 \%$ in 2004 , which was only $0.04 \%$ shy of the 2004 's primary school enrolment rate of boys (ibid).By the spring of 2005, the Ministry of Education regulated that primary school and junior secondary school students nationwide could not be charged more than 160 yuan (US\$23.5) and 260 yuan (US\$38.2) per year respectively (Chyi \& Zhou, 2014, p. 105). In 2008, the primary school net enrolment ratio was $99.54 \%$ for all children, where the ratio for girls was as high as $99.58 \%$. In the same year, the transition ratio to junior secondary school reached 99.7\%, hinting that most girls were able to attend junior secondary school (Hannum, An, \& Cherng, 2011, p. 269). Additionally, the senior secondary school transition ratio was at $83.4 \%$ in 2008 from $50.3 \%$ in 1995 . These statistics implied that there was a rapid growth for children to attend non-compulsory education, despite a significant proportion of children were still deprived of their senior secondary education opportunities (ibid: $p$. 270).

Gender parity in compulsory education, and therefore the EfA goals have been almost completely attained. However, in the least financially secure regions, girls continue to be subject to educational deprivation. The educational and social inequalities faced by poor rural girls stem from the entrenched Confucian cultures. Confucianism highlights the importance for each household unit to be ordered hierarchically, with the male ruler at the top and the youngest daughter at the bottom. The culture emphasises on "three obedience", requiring each girl and woman to fulfil their duties by obeying their fathers before marriage, their husbands after marriage and 
their sons after the husbands' death. Women are usually held responsible for domestic finances and household duties, yet eschewing accomplishments beyond their household units (Granrose, 2007, p. 10). The gendered Confucianism renders the vulnerability of girls within household settings, resulting in the lack of parental expectations on, and investment in, daughters' development within and beyond educational contexts. Gender division of labour is also widely practiced in households in underdeveloped regions where women and men are assigned to perform certain tasks on the basis of their natural aptitudes and capabilities (Kabeer 1994: p. 59). Here men predominantly provide the means of subsistence while women focus on the production and reproduction of human life (ibid: p. 44). Men are entitled to the privileges to domesticate women and restrict the latter to the role of, mainly, breeding and rearing children (ibid: p. 51). In household and school settings, parents and teachers respectively often reproduce the beliefs that girls are failing and unconfident. The culturally and socially prescribed and gendered identities prompt girls to believe that they are not as competitive as boys and their future is mapped out in terms of marriage but not academic excellence (Aikman \& Rao, 2012, p. 221).

The traditional patrilocal marriage system compounded parents' unwillingness to send daughters to school since girls are viewed as responsible for the old-age support of their parents-in-laws (Tsui \& Rich, 2002, p. 78; He, 2018). Based on data from 2000 Gansu Survey of Children and Families (GSCF), Qihui Chen (2012, p. 26) revealed that approximately $20 \%$ of a sample of 2,000 rural parents believed sending daughters to school is unnecessary as they would eventually marry out. A major reason for son preference for schooling is due to the mindset that sons are usually held responsible for old-age support for their own parents. Such a belief is still profound in impoverished rural areas despite China's 1982 Marriage Law has mandated all daughters to be responsible for their parents' old-age support (ibid: p. 29). An additional study conducted in Yunnan Province and Gansu Province echoed by stating that most rural mothers expect financial support from sons rather than daughters where such a gendered parental expectation is tied to the aspirations for children's educational success (Cherng \& Hannum, 2013, p. 633). These findings help explain why the maldistribution of educational resources by gender can still be seen in least developed regions. The Central Government might consider strengthening the enforcement of the marriage law by fining, or cutting the social welfare enjoyed by, both the male and female workforce who fail to take up the responsibilities to give old-age support to their own parents. Such a suggested policy can assure that both sons and daughters make almost, if not totally, equal financial contribution to their households, and thus, gender inequalities in parental expectations on children's educational success could potentially be minimised in the long-term. As a result, in least educationally developed regions, rural poor girls could, hence, be entitled to opportunities for more promising academic development.

Rural schools and families are gendered institutions where gender stereotypes, prejudice and norms reproduce the barriers to poor girls' academic success (Robeyns, 2007, p. 60; Aikman \& Ran, 2012, p. 221). Supported by the GAD approach, gendered power structures in educational inequalities in cultural, institutional, social and economic contexts have to be challenged politically through the encouragement of female participation in decision making (Aikman \& Unterhalter, 2005, p. 23). It is crucial for local governments to legitimise gender equality as a fundamental value which is reflected in institutional practices and development choices in multifaceted contexts. Local governments' expenditures that could yield developmental benefits to women and girls should be identified and highlighted (ibid: p. 26). By then, impoverished rural regions practicing entrenched Confucian cultures could be increasingly liberalised and the problems of gender inequalities in education could be lessened gradually.

To enhance rural girls' powers of decision-making, it is noteworthy that having political affiliation is a direct way for them to gain entry to upper-tier universities and work as a rural cadre in villages. Because the Communist Party of China (CPC) does not actively recruit political members in rural areas, party membership is generally not accessible to ordinary peasants. A popular strategy for rural youths to seek political affiliation is to join the People's Liberation Army (PLA) and then to acquire CPC membership while serving in the army (Wu \& Treiman, 2004, p. 366; Li, 2010, p. 4). Therefore, both the Central Government and local governments could encourage rural girls to participate in the army and, in the long-term, raise the ratios of female participation in the skilled labour market and political sector.

Currently, with the lack of female decision-making powers, most financially insecure parents prefer sending daughters to work as child labours for the survival of families. Again female vulnerability is reproduced, fostering poor rural girls to believe that they are subordinate and unworthy (Seeberg et al., 2007, p. 128). Huajing He (2016, p. 148) found that more than one hour of child labouring per day has a negative effect on rural children's academic performance four years later. Here girls are subject to five to six percentage point higher probability of child labouring, relative to their male counterparts (ibid). Raising poor rural girls' decision-making powers may therefore be essential to improve educational equalities by gender, as these girls 
can, to a larger extent, resist working as child labours and focus more on their academic development. Further research should be developed to study whether parental or alternative factors are confounders that cause child labouring to produce changes on children's academic performance, in order to understand if the Central Government and local governments should intervene gendered parental or otherwise perceptions on child development and tackle the problems of, especially girls', child labouring efficiently.

Among educationally underdeveloped regions, education investment in girls in rural West of China, such as Tibet, is of particularly urgent needs. In these regions, in order to facilitate the entitlement of nine year compulsory education to all girls, the Chinese Children and Teenager Foundation (CCTF), an American NGO which was administered by All China Women's Federation (ACWF), launched the Shaanxi Spring Bud Scholarship Programme (SBP) in 2001 (Ross \& Wang, 2008, p. 91). SBP is China's largest Spring Bud initiative (Ross, Shah, \& Wang, 2011, p. 31). To date, the SBP has provided scholarships to thousands dropout schoolgirls, aged between nine and 16, to study fourth grade primary education through senior secondary education or vocation education (ibid). A sum of 138 female recipients of scholarships continued to attend fully funded tertiary education (ibid: p. 32). SBP girls could avoid premature marriage or child labouring. They were also more ambitious in terms of their career development, actively seeking jobs that could lead to economic independence and the provision of old-age support to parents (ibid: p. 38). Poor local governments might not be financially able to set up an initiative and fund their female villagers to undertake both compulsory and non-compulsory education, and the Central Government might be reluctant to organise and fund such an initiative in impoverished areas due to relatively low social returns. However, relying solely on NGOs to develop such a programme might only be able to benefit a limited number of beneficiaries due to financial constraints and the programme might be more likely to terminate if NGOs cannot ensure its financial sustainability. Therefore, the Central Government and local governments might consider working jointly with relevant NGOs to deliver funding to disadvantaged school-aged villagers, especially girls, where the state and NGOs can share the financial, administrative and otherwise workloads to run such a programme.

In better-off and -developed rural areas, alternatively, girls have largely been able to school. Farming has also predominantly been abandoned. These girls, alongside their family members, understand that educational investment in girls can lead to a better life for the entire households and their next generations (Seeberg et al., 2007, p. 57). Girls, additionally, became a focal point in the 2003 Care-for-Girls campaign that promoted "changing the traditional preference for boys to girls' legitimate rights and interests, and striving to enhance their status in the family" (Ross et al., 2011, p. 31). Among more financially secure households, parents experience less stringent economic pressure to choose which children to receive education. These parents often have more gender-equitable aspirations for their children in educational, social and otherwise settings (Deng et al., 2014, p. 185).

\section{Conclusions}

This essay explains why least financially secure parents prioritise the investment in sons' rather than daughters' educational competitiveness due to financial shortages, expectations of higher economic returns from sons, and practices of gender hierarchy and its implications of girls' subordination. This essay also illustrates that parents still prefer spending financial resources on sons' rather than daughters' further education when compulsory education costs are exempted or largely subsidised. As an outcome, gender disparities in education could only be limitedly narrowed by contemporary state and NGOs' intervention. Furthermore, this essay demonstrates that the Central Government's legislation requires both sons and daughters to financially support their own parents soon when they become economically independent. Yet, gender stereotypes and prejudice on the lack of economic returns given by daughters remain. Therefore, economic factors are seemingly not the root of educational inequalities by gender in least developed Chinese regions. It might plausibly be the gendered structure of powers which devalue female status in domestic, educational and labour market settings, and therefore, lead to the persistence of educational inequalities.

In better-off and -developed rural areas, local governments have the capacity, and are willing, to fully or mostly subsidise unprivileged children's education-related expenses. More importantly, from a cultural prospective, rural girls and their parents recognise that educational investment in girls can lead to the latter's economic independence, and delivery of more economic returns to parents and other household members (Seeberg et al., 2007, p. 57). Based on these arguments, it is worth exploring, in future research, whether rural parents from least financially secure villages can realise the economic gains from sending children, especially girls, to school in the longer-term insofar as the Central Government is willing to take up more financial responsibilities to exempt or subsidise educational expenses in most impoverished regions. In addition, future research should emphasise on studying whether rural children gaining political memberships by joining the army or otherwise can alter the 
gendered structure of powers and enhance girls' status in household or alternative settings. These suggested research focuses could potentially address the structural barriers to education faced by rural poor girls.

\section{Referenes}

Abbasi, N., Ping, J., \& Shaikh, S. (2017). Left-Behind Girl Child Safety Problems in Rural China. International Research Journal of Arts \& Humanities, 45(45), 225-232. https://doi.org/10.1111/j.1741-3737.2011.00951.x

Aikman, S., \& Rao, N. (2012). Gender Equality and Girls' Education: Investigating Frameworks, Disjunctures and Meanings of Quality Education. Theory and Research in Education, 10(3), 211-228. https://doi.org/10.1177/1477878512459391

Aikman, S., \& Unterhalter, E. (2005). Beyond Access: Transforming Policy and Practice for Gender Equality in Education. Oxford: Oxfam.

Brauw, A. D., \& Rozelle, S. (2007). Reconciling the Returns to Education in Off-Farm Wage Employment in Rural China. Review of Development Economics, $12(1), \quad 57-71$. https://doi.org/10.1111/j.1467-9361.2007.00376.x

Brown, E., \& Zong, G. (2017). Global Perspectives on Gender and Sexuality in Education. Charlotte, N.C.: Information Age Publishing, Inc.

Calkin, S. (2015). Feminism, Interrupted? Gender and Development in the Era of "Smart Economics". Progress in Development Studies, 15(4), 295-307. https://doi.org/10.1177/1464993415592737

Chen, Q. (2012). Three Essays on Human Capital Investment in China. A Dissertation Submitted to the Faculty of University of Minnesota in Partial Fulfilment of the Requirements for the Degree of Doctor of Philosophy.

Cherng, H., \& Hannum, E. (2013). Community Poverty, Industrialisation, and Educational Gender Gaps in Rural China. In Communities, Poverty, and Educational Gender Gaps (pp. 659-690). Oxford University Press.

Chyi, H., \& Zhou, B. (2014). The Effects of Tuition Reforms on School Enrolment in Rural China. Economics of Education Review, 38(1), 104-123. https://doi.org/10.1016/j.econedurev.2013.11.003

Deng, M., \& Kim, F. (2004). Inclusive Education in China: Conceptualisation and Realisation. Asia Pacific Journal of Education, 24(2), 143-156. https://doi.org/10.1080/02188791.2004.10600206

Deng, S., Huang, J., Jin, M., \& Sherraden, M. (2014). Household Assets, School Enrolment, and Parental Aspirations for Children's Education in Rural China: Does Gender Matter? International Journal of Social Welfare, 23(2), 185-194. https://doi.org/10.1111/ijsw.12034

Ding, Y. (2008). The Challenges in Building an Adequate and Comprehensive Fund-Ensuring System for Rural Compulsory Education in China: Empirical Evidence from the Implementation of "Two Exemptions and One Subsidy" (TEOS). Chinese Education \& Society, 41(1), 30-36. https://doi.org/10.2753/CED1061-1932410112

Dollar, D. (2007). Poverty, Inequality, and Social Disparities During China's Economic Reform. World Bank Policy Research Working Paper No. 4253.

Dong, N., Zhang, J., Delprino, R., \& Zhou, L. (2009). Psychological Strains Found from In-depth Interviews with 105 Chinese Rural Young Suicides. Archives of Suicide Research, 13(2), 185-194. https://doi.org/10.1080/13811110902835155

Epstein, I. (2017 [1991]). Chinese Education: Problems, Policies and Prospects. London: Routledge.

Fan, S., Zhang, L., \& Zhang, X. (2004). Reforms, Investment, and Poverty in Rural China. In Economic Development and Cultural Change (pp. 395-421). Chicago, I.L.: The University of Chicago.

Fong, E., \& Tong, Y. (2015). Can Family Financial Resources Buy Friends? Family Financial Resources and Friendship Patterns among Migrant Workers in China. American Behavioural Scientist, 59(9), 1083-1099. https://doi.org/10.1177/0002764215580615

Fu, Y., \& Liu, S. (2006). Considerations about the Construction of the New Mechanism for Rural Compulsory Education Assured Funding. Studies on Education Book-Keeping and Accounting, 4(1), 38-41.

Golley, J., \& Kong, S. (2013). Inequality in Intergenerational Mobility of Education in China. China \& World Economy, 21(2), 15-37. https://doi.org/10.1111/j.1749-124X.2013.12013.x

Gong, X., Soest, A., \& Zhang, P. (2005). The Effects of the Gender of Children on Expenditure Patterns in Rural 
China: A Semiparametric Analysis. Journal of Applied Econometrics, 20(4), 509-527. https://doi.org/10.1002/jae.780

Granrose, C. (2007). Gender Differences in Career Perceptions in the People's Republic of China. Career Development International, 12(1), 9-27. https://doi.org/10.1108/13620430710724802

Hannum, E. (2005). Market Transition, Educational Disparities, and Family Strategies in Rural China: New Evidence on Gender Stratification and Development. Demography, 42(2), 275-99. https://doi.org/10.1353/dem.2005.0014

Hannum, E., An, X., \& Cherng, H. (2011). Examinations and Educational Opportunity in China: Mobility and Bottlenecks for the Rural Poor. Oxford Review of Education, 37(2), 267-305. https://doi.org/10.1080/03054985.2011.559387

Hannum, E., Kong, P., \& Zhang, Y. (2009). Family Sources of Educational Gender Inequality in Rural China: A Critical Assessment. International Journal of Educational Development, 29(2), 474-486. https://doi.org/10.1016/j.ijedudev.2009.04.007

Hannum, E., Park, A., Brauw, A., \& Rozelle, S. (2012). Returns to Education in Rural China. REAP Papers 22569. Stanford, C.A.: Rural Education Action Project (REAP), Stanford University.

He, H. (2016). Child Labour and Academic Achievement: Evidence from Gansu Province in China. China Economic Review, 38(1), 130-150. https://doi.org/10.1016/j.chieco.2015.12.008

He, L. (2018). Female Underrepresentation in STEM Subjects: A Study of Female High School Student in China (Master Degree Thesis, Faculty of Graduate Studies, Faculty of Education, University of Windsor).

Hung, J. (2020). Psychosocial Wellbeing among Rural Migrant Workers in China: Did the 2008 Financial Crisis Worsen Their Vulnerability? Asian Social Science, 16(1), 54-68. https://doi.org/10.5539/ass.v16n1p54

Jaquette, J. (2017). Women/Gender and Development: Thee Growing Gap Between Theory and Practice. Studies in Comparative International Development, 52(2), 242-260. https://doi.org/10.1007/s12116-017-9248-8

Kabeer, N. (1994). Same Realities, Different Windows: Structuralist Perspectives on Women and Development. Reversed Realities: Gender Hierarchies in Development Thought (pp. 40-68). London: Verso.

Kipnis, A. (2011). Governing Educational Desire: Culture, Politics, and Schooling in China. Chicago, I.L.: The University of Chicago.

Knight, J., Shi, L., \& Quheng, D. (2010). Education and the Poverty Trap in Rural China: Closing the Trap. Oxford Development Studies, 38(1), 1-24. https://doi.org/10.1080/13600810903551595

Knight, J., Sicular, T., \& Yue, X. (2013). Educational Inequality in China. In L. Shi (Ed.), Rising Inequality in China: Challenges to a Harmonious Society (pp. 142-196). Cambridge: Cambridge University Press.

Koczberski, G. (1998). Women in Development: A Critical Analysis. Third World Quarterly, 19(3), 395-409. https://doi.org/10.1080/01436599814316

Lee, J., Yu, Z., Huang, X., \& Law, E. (2016). Educational Development in Western China: Towards Quality and Equity. Taipei: Springer.

Lee, M. (2011). Migration and Children's Welfare in China: The Schooling and Health of Children Left-Behind. The Journal of Developing Areas, 44(2), 165-182. https://doi.org/10.1353/jda.0.0104

Li, C. (2010). China's Emerging Middle Class: Beyond Economic Transformation. Washington D.C.: Brookings Institution Press.

Liu, F. (2004). Basic Education in China's Rural Areas: A Legal Obligation or an Individual Choice? International J. of Educational Development, 24(1), 5-21. https://doi.org/10.1016/j.ijedudev.2003.09.001

Liu, J. (2008). The Most Disadvantaged: An Examination and Analysis of Rural Girls' Access to Higher Education in China (Master Degree Thesis, Kent State University College and Graduate School of Education, Health and Human Services).

Liu, J., McMahon, M., \& Watson, M. (2015). Parental Influence on Mainland Chinese Children's Career Aspirations: Child and Parental Perspectives. International Journal for Educational and Vocational Guidance, 15(1), 131-43. https://doi.org/10.1007/s10775-015-9291-9

Lu, S., Lin, Y., Vikse, J., \& Huang, C. (2016). Well-Being of Migrant and Left-Behind Children in China: Education, Health, Parenting and Personal Values. International Journal of Social Welfare, 25(1), 58-68. 
https://doi.org/10.1111/ijsw.12162

$\mathrm{Lu}$, Y. (2012). Education of Children Left Behind in Rural China. Journal of Marriage and Family, 74(2), 328-341. https://doi.org/10.1111/j.1741-3737.2011.00951.x

Meng, L. (2007). Considerations about a Number of Questions in the Rural Compulsory Education Assured Funding Mechanism Reform: Report on Investigations and Research into Baise's Rural Compulsory Education Assured Funding Mechanism Reform. Inner Mongolia Normal University Journal, 20(1), 22-26.

Park, A. (2007). Rural-Urban Inequality in China. In S. Yusuf, \& T. Saich, (Eds.), China Urbanizes: Consequences, Strategies and Policies (pp. 41-64). Washington, D.C.: The World Bank.

Robeyns, I. (2006). Three Models of Education Rights, Capabilities and Human Capital. Theory and Research in Education, 4(1), 69-84. https://doi.org/10.1177/1477878506060683

Rong, X., \& Shi, T. (2001). Inequality in Chinese Education. Journal of Contemporary China, 10(26), 107-24. https://doi.org/10.1080/10670560124330

Ross, H., \& Wang, L. (2008). Learning to Lead Challenging Girls in Rural Chinese Schools. Girlhood Studies, 1(1), 81-113. https://doi.org/10.3167/ghs.2008.010106

Ross, H., Shah, P., \& Wang, L. (2011). Situating Empowerment for Millennial Schoolgirls in Gujarat, India and Shaanxi, China. Feminist Formations, 23(1), 23-47

Rotary District 3450. (n. d.). 扶輪服務中國 [Rotary's Services in China]. Retrieved from https://rotary3450.org/扶輪服務中國/

Rural Education Action Program (REAP). (2007). Barriers for the Rural Poor on the Road to College: New Evidence from REAP. REAP Brief 107.

Seeberg, V. (2011). Schooling, Jobbing, Marrying: What's a Girl to Do to Make Life Better? Empowerment Capabilities of Girls at the Margins of Globalisation in China. Research in Comparative and International Education, 6(1), 43-61. https://dx.doi.org/10.2304/rcie.2011.6.1.43

Seeberg, V., Ross, H., Liu, J., \& Tan, G. (2007). Grounds for Prioritising Education for Girls: The Telling Case of Left-Behind Rural China. International Perspectives on Education and Society, 8(1), 109-154. https://doi.org/10.1016/S1479-3679(06)08004-2

Shi, X. (2016). The Impact of Educational Fee Reduction Reform on School Enrolment in Rural China. The Journal of Development Studies, 52(12), 1791-1809. https://dx.doi.org/10.1080/00220388.2016.1156094

Shi, Y., Zhang, L., Ma, Y., Yi, H., Liu, C., Johnson, N., Chu, J., Loyalka, P., \& Rozelle, S. (2015). Dropping Out of Rural China's Secondary Schools: A Mixed-Methods Analysis. The China Quarterly, 224(1), 1048-1069. https://doi.org/10.1017/S0305741015001277

Stromquist, N. (2015). Gender Structure and Women's Agency: Toward Greater Theoretical Understanding of Education for Transformation. International Journal of Lifelong Education, 34(1), 59-75. https://doi.org/10.1080/02601370.2014.991524

Su, S. (2011). Property Ownership and Private Higher Education in China: On What Grounds. New York, N.Y.: Lexington Books.

Tang, C., Zhao, L., \& Zhao, Z. (2020). Does Free Education Help Combat Child Labour? The Effect of a Free Compulsory Education Reform in Rural China. Journal of Population Economics, 33(2), 601-631. https://doi.org/10.1007/s00148-019-00741-w

The Organisation for Economic Co-operation and Development (OECD). (2016). Education in China: A Snapshot. Paris: OECD Publishing.

The World Bank. (2020a). China. Retrieved from https://data.worldbank.org/country/china

The World Bank. (2020b). Rural Population (\% of Total Population) - China. Retrieved from https://data.worldbank.org/indicator/SP.RUR.TOTL.ZS?locations $=\mathrm{CN}$

Tsui, M., \& Rich, L. (2002). The Only Child and Educational Opportunity for Girls in Urban China. Gender and Society, 16(1), 74-92. https://doi.org/10.1177/0891243202016001005

Unterhalter, E., \& North, A. (2010). Assessing Gender Mainstreaming in the Education Sector: Depoliticised Technique or a Step Towards Women's Rights and Gender Equality. Compare, 40(4), 389-404. https://doi.org/10.1080/03057925.2010.490358 
Wang, F., Zhou, X., \& Hesketh, T. (2017). Psychological Adjustment and Behaviours in Children of Migrant Workers in China. Child: Care. Health and Development, 43(6), 884-890. https://doi.org/10.1111/cch.12499

Wang, S., \& Mao, Y. (2018). The Effect of Boarding on Campus on Left-Behind Children's Sense of School Belonging and Academic Achievement: Chinese Evidence from Propensity Score Matching Analysis. Asia Pacific Journal of Education, 38(3), 378-93. https://doi.org/10.1080/02188791.2018.1470965

Wang, X. (2010). Girls' Access to Education in China: Actors, Cultures and the Windmill of Development Management. London: The Institute of Education, University of London.

Wang, Y. (2018). Educational and Nutritional Consequences of Education Subsidy in Rural China. China Economic Review, 51(1), 167-180. https://doi.org/10.1016/j.chieco.2018.03.004

Wanner, T., \& Wadham, B. (2015). Men and Masculinities in International Development: Men-Streaming. Gender and Development, 33(1), 15-32. https://doi.org/10.1111/dpr.12090

Wu, X., \& Treiman, D. (2004). The Household Registration System and Social Stratification in China: 1955-96. Demography, 41(2), 363-384. https://doi.org/10.1353/dem.2004.0010

Xue, E., \& Zhou, X. (2018). Education and Anti-Poverty: Policy Theory and Strategy of Poverty Alleviation through Education in China. Educational Philosophy and Theory, 50(12), 1101-1112. https://doi.org/10.1080/00131857.2018.1438889

Yang, X. (2010). Access to Higher Education for Rural-Poor Students in China. Educational Research for Policy and Practice, 9(3), 193-209. https://doi.org/10.1007/s10671-010-9084-3

Yeung, J. (2013). Higher Education Expansion and Social Stratification in China. Chinese Sociological Review, 45(4), 54-80. https://doi.org/10.2753/CSA2162-0555450403

Yiu, L., \& Adams, J. (2013). Reforming Rural Education in China: Understanding Teacher Expectations for Rural Youth. The China Quarterly, 216(216), 993-1017. https://doi.org/10.1017/S0305741013001136

Yue, A., Tang, B., Shi, Y., Tang, J., Shang, G., Medina, A., \& Rozelle, S. (2017). Rural Education Across China's 40 Years of Reform: Past Successes and Future Challenges. China Agricultural Economic Review, 10(1), 93-118. https://doi.org/10.1108/CAER-11-2017-0222

Zhang, J., Xiao, S., \& Zhou, L. (2010). Mental Disorders and Suicide among Young Rural Chinese: A Case-Control Psychological Autopsy Study. American Journal of Psychiatry, 16(7), 773-781. https://doi.org/10.1176/appi.ajp.2010.09101476

Zhang, L., \& Liu, J. (2007). China's Juvenile Delinquency Prevention Law. International Journal of Offender Therapy and Comparative Criminology, 51(5), 541-554. https://doi.org/10.1177/0306624X06292675

Zhang, S., \& Hou, X. (2006). A Major Systemic Innovation in the History of Development of Compulsory Education. Yibu Education Research, 5(1), 33-35.

Zhao, F., \& Yu, G. (2016). Parental Migration and Rural Left-Behind Children's Mental Health in China: A Meta-Analysis Based on Mental Health Test. Journal of Child Family Studies, 23, 3462-72. https://doi.org/10.1007/s10826-016-0517-3

Zhao, M., \& Glewwe, P. (2009). What Determines Basic School Attainment in Developing Countries? Evidence from Rural China. Gansu Survey of Children and Families Papers 13.

Zhou, C., Sylvia, S., Zhang, L., Luo, R., Yi, H., Liu, C., Shi, Y., Loyalka, P., Chu, J., Medina, A., \& Rozelle, S. (2015). China's Left-Behind Children: Impact of Parental Migration on Health, Nutrition, and Educational Outcomes. Health Affairs, 34(11), 1964-1971. https://doi.org/10.1377/hlthaff.2015.0150

Zhou, D. (2006). The New Mechanism: Perfecting the Course of Implementation. Education Biweekly, 7(1), $22-26$.

Zhou, H. (2012). Promoting Compulsory Education in Rural China: What Are the NPOs Doing? Frontiers of Education in China, 7(4), 576-607. https://doi.org/10.1007/BF03396955

\section{Copyrights}

Copyright for this article is retained by the author(s), with first publication rights granted to the journal.

This is an open-access article distributed under the terms and conditions of the Creative Commons Attribution license (http://creativecommons.org/licenses/by/4.0/). 